\title{
Preliminary reflections on teaching about ethnic minorities in law
}

\author{
Prakash A. Shah* \\ Now published in: (2003) The Law Teacher Vol. 37, No. 1, pp. 18-35.
}

I have been teaching Ethnic Minorities and the Law at undergraduate and Masters level for some eight years now. It is my conviction that the subject has achieved certain maturity and that it is high time that it was taken serious notice of in legal education circles at all levels. This article presents some reflections on approaches adopted and experiences of being involved in teaching this field. In the next section some of the reactions that are likely to be encountered when working in this area are discussed briefly. In the following section the nature and extent of ethnic diversity in the UK are outlined, and some of the limits in academic and policy conceptualisations of this diversity are highlighted. There follows a critical discussion of the various paradigms within which legal knowledge has framed discussion relating to ethnic minorities in the UK. This forms a prelude to the introduction of legal-pluralist perspectives which, it is argued, offer the most positive approach in the area of ethnic minority legal studies. Lastly, some of the practical issues that arise in teaching about ethnic minorities in law are discussed.

\section{Student and academic perceptions}

I started off co-teaching Ethnic Minorities and the Law as a timid postgraduate student at the School of Oriental and African Studies (SOAS), University of London, where Werner Menski had broken the mould, a few years previously, by introducing the first such course in the UK. I had actually been a student on the same course two years prior to that, a sort of refugee from a not-far-from-typical-law programme elsewhere in the University of London. As I continued with my doctorate I began to be more and more immersed in teaching this course, together with an assortment of other offerings on under- and post-graduate programmes. In $2001 \mathrm{I}$ started to teach a similar, but much more compact, undergraduate course at the University of Kent at Canterbury, and now teach the same subject at under and post-graduate levels at Queen Mary, University of London.

The questions that we were asking on our courses were also reflected in wider European debates, as I saw while teaching for five years in the 1990s on an inter-university course on migration and 'inter-culturalite hosted annually by INALCO in Paris. While at Kent I therefore began to build on this experience and to think about how the question of ethnic minorities and the law could be taught and discussed in a postgraduate course focusing on migration issues in Europe. I was struck and heartened by the level of interest for my tentative introduction of the topic of the legal situation of Muslims in Western Europe. ${ }^{1}$

Indeed, it is remarkable that student interest for courses tackling these topics has generally tended to be quite high. Although I am convinced about this, we have noticed that a number of reservations also preoccupy students when considering taking up such courses. Not least among these are worries about being marginalized or penalised in the job market. In our experience, this has largely not been the case in actual practice and there is evidence that older lawyers are rewarding students who have under their belts the sorts of qualifications that they

\footnotetext{
* Lecturer, Department of Law, Queen Mary, University of London: prakash.shah@qmul.ac.uk. This is a revised and updated version of a paper delivered at the Association of Law Teachers Annual Conference, University of Greenwich in March 2002 and at the Socio-Legal Studies Association conference, University of Wales, Aberystwyth in April 2002.

${ }^{1}$ On the salience of this issue Europe-wide see, for example, Ferrari, S. and A. Bradney (eds.) [2000]: Islam and European legal systems. Aldershot: Ashgate.
} 
themselves never got the chance to study. The ever-increasing emphasis on diversity-aware workers provides an added incentive in this context. ${ }^{2}$

Another reservation tends to come from white English students that such courses are simply not for them, with the result that almost all the students who end up staying on the courses tend to be of Asian or African origin themselves. An ever-present worry for us is therefore the possible 'ghettoisation' of the discipline. More worrying is the assumption that white-English law students do not need to know about the legal implications of increasing cultural pluralisation within British or European societies. I say specifically 'white-English' because my experience at SOAS and Kent proved to me that there is a lively interest in these topics among students from continental Europe as well as North America who are pleasantly surprised about such innovations in legal education in Britain as compared to their own jurisdictions, while being aware that demographic changes in their home countries pose similar questions there too. In this larger context one may legitimately question who is being ghettoised, or rather is self-ghettoising. Another important trend has been that the overwhelming majority of students are tending to be female, and there is cause for thinking about whether and why ethnic minority studies in law are also gender-coded in students' minds. There appear to be obvious parallels here with Family Law and Women and the Law courses which attract mainly female students.

There is, predictably, reluctance about the topics taught or approaches taken within law departments too where fellow academics can often be dismissive due to prevailing orthodoxies or latent fears. On the other hand, my appointments at Kent and Queen Mary were made specifically because I had had experience teaching ethnic minorities and law as well as immigration law. This may tell us something about the slow but sure recognition of the subject as universities increasingly come under pressures to make their offerings more market-friendly, but also that some law departments genuinely wish to broaden their focus in the post-MacPherson era by taking diversity issues more seriously. There are inevitably also implications flowing from the fact that someone like myself, coming from an East African Gujarati background, teaches such a course. It may mean further ghettoisation, combined ironically with a perception of greater legitimacy. Both results carry their own dangers. ${ }^{3}$

\section{Ethnic diversity in the UK}

Teaching ethnic minorities and law cannot avoid some analysis of the demographic character of British society and how it is conceptualised. In our courses the minorities of key interest are those from Asia, Africa and the Caribbean. This approach inherently poses problems and might provoke accusatory responses. Are we not excluding concerns about 'white' ethnic minorities? Do we not consequently problematise the presence of non-white ethnic minorities? Do we not thereby legitimate skin colour distinctions, and thus outmoded social Darwinist notions of 'race', as a point of departure? What these criticisms point to is that the whole notion of ethnicity has to be problematised in a way that takes it beyond narrow notions of racial dualism. In that sense, the

${ }^{2}$ For a recent confirmation of this see Sappal, P. [2002]: 'In demand: transcultural managers'. In: Expatica Jobs at www.expatica.com. Gidoomal, R., D. Mahtani and D. Porter [2001]: The British and how to deal with them. Doing business with Britain's ethnic communities. London: Middlesex University Press, make the point even more explicit and compelling, arguing that lack of awareness of ethnic diversity and a lack of inter-cultural competence results in huge loses to the UK economy.

${ }^{3}$ Menski, W. [1997]: 'Race and law'. In: Ireland, P. and Laleng, P. (eds.): The critical lanyers' bandbook 2. London and Chicago: Pluto Press, pp. 61-75, at p. 72 critically observes "If the experience of schools is a pointer, it could be disastrous to expect non-white colleagues to shoulder 'ethnic' subjects - the point is precisely that ethnic minority legal issues concern us all." I am currently exercised by the possibility that being of Hindu or Jain background predisposes one to be plurality-aware to a radical degree given the postulates of this cultural heritage. Of the several writers who are contributing to the field of multiculturalism in the UK within a plurality framework one could name Lord Bhikhu Parekh, Ram Gidoomal, Shamit Saggar and Dilip Hiro who all share this background too. 
question of 'white' ethnicities is one of the central issues that needs to be confronted. It is entirely defensible, and in fact necessary, that white ethnicities in Britain be discussed in the context of debates on ethnic plurality and law. Our concentration is, nevertheless, accounted for partly because of our linkage to an institution that was primarily focused on the study of AfroAsian cultures. ${ }^{4}$ Teaching about ethnic minorities as part of a law curriculum was thus pioneered as a response to the diasporic establishment of Afro-Asian cultures in Britain in a radical way since the end of Second World War, and the myriad legal issues that this was throwing up. ${ }^{5}$

While the Afro-Asian presence has been evident in Britain for centuries, as a number of recent historical works have demonstrated ${ }^{6}$, it is the post-Second World War history of immigration that has left lasting and long-term implications for the British social order. ${ }^{7}$ It appears that policymakers in top government circles were discussing the potential implications, in terms of social peace, of the immigration of people from various parts of the British Empire and Commonwealth in the Caribbean, Asia and Africa from the late 1940s. Given the continued need to overcome post-war labour shortages, recruitment on a large scale in far-flung territories continued despite concerns about the gradually increasing presence of non-Europeans in Britain. The earlier, state-sponsored immigration of European Volunteer Workers in their hundreds of thousands was never to provoke such hidden resentment.

Once hostility against non-European workers had been openly expressed in racist violence in the late 1950s in places like Nottingham and Notting Hill, it seemed to also become acceptable to overtly advocate the curtailment of their settlement rights. ${ }^{8}$ This pattern was repeated with alarming frequency and continuity with every significant piece of immigration legislation since the Commonwealth Immigrants Act 1962. ${ }^{9}$ That Act had itself indirectly begun to affect the character of migration patterns in the UK as worker migration began to give way to large-scale family reunion, which continues in different ways to this day, as do parallel processes of transnational family formation. The post-war history of the Britain's urban industrial centres has thus been characterised by a changing cultural landscape with the formation of colonies of Afro-Asians. It is this demographic change, overlain in more recent years with refugee migrations from various parts of the globe, which has led to the raising of extremely important questions about the ethnic nature of the British social order.

4 I use the term 'Afro-Asian' as shorthand for 'Asian and African'. The use of the hyphen here does not bear the same connotations as in the notion of hyphenated identities such as 'BritishAsian' or 'Scottish-Muslim', but more in the sense of 'Anglo-American'.

${ }^{5}$ Derrett, J. D. M. [1976]: Essays in classical and modern Hindu law. Volume 1. Leiden: E.J. Brill, p. vii hinted that practical concern about Hindu law outside South Asia, South-East Asia and East Africa was revived by the arrival of "the massive immigrations of Hindus and Sikhs into Britain." Derrett was then Professor of Oriental Laws at SOAS.

${ }^{6}$ Fryer, P. [1984]: Staying power. The bistory of black people in Britain. London: Pluto Press; Ramdin, R. [1999]: Reimaging Britain: 500 Years of Black and Asian History. London: Pluto; Lahiri, S. [1999]: Indians in Britain: Anglo-Indian encounters, race and identity. London: Frank Cass; Visram, R. [2002]: Asians in Britain: 400 years of history. London: Pluto.

7 Ballard, R. [1994]: 'Introduction'. In: Ballard, R. (ed.): Desh Pardesh. The South Asian presence in Britain. London: Hurst and Co., pp. 1-34 at pp. 1-3. Ballard here prognosticates that the change wrought by post-war immigration in Britain may prove to have as much of a profound impact in the longer term, as did the Norman irruption.

${ }^{8}$ For an account of the period see Ramdin [1999], op cit, pp. 176-183. Also in detail, Phillips, M and T. Phillips [2000]: Windrush: The irresistible rise of multi-racial Britain. London: Harper Collins, pp. 158-188 on Notting Hill and Nottingham; Pilkington, E. [1996]: 'The West Indian Community and the Notting Hill Riots of 1958'. In: Panayi, P. (ed.): Racial violence in Britain in the nineteenth and twentieth Centuries. London and New York: Leicester University Press, pp. 171-184.

${ }^{9}$ A number of general studies cover the history and development of immigration controls in the UK, notably: Evans, J. [1983]: Immigration law. 2nd ed. London: Sweet and Maxwell; Bevan, V. [1986]: The development of British immigration law. London et al: Croom Helm; Dummett, A. and A. Nicol [1990]: Subjects, citizens, aliens and others: Nationality and immigration law. London: Weidenfeld and Nicolson; Juss, S. [1993]: Immigration, nationality and citizenship. London: Mansell; Shah, P. [2000]: Refugees, race and the legal concept of asylum in Britain. London: Cavendish. 
Since the end of the Second World War a major challenge for policymakers in Britain has been to find an adequate conceptual mechanism to capture the character of the ethnic minority presence. Social science and policy understandings came to be dominated by discourses on racial exclusion and deprivation as the so-called 'race relations' industry flourished. Roger Ballard has observed how racial discrimination was diagnosed as the key problem, which was then seen as reinforcing the well-known phenomenon of class inequality, within which framework the problems of the new minorities, it was advocated, had to be understood. ${ }^{10}$ However, this approach typecast their situation within a 'deprivationist' frame that neglected the varied goals of the groups and individuals concerned. It was nevertheless one into which many ethnic minority 'spokespersons' were co-opted. Under its influence the salience of ethnicity, culture or religion as operational characteristics was hardly investigated. While it is certain that skin colour is constantly used as a marker to discriminate, to concentrate one's analytical efforts solely on this marker was to neglect how the minorities' agency is harnessed, not only for resistance to discrimination and penalisation for non-conformity, but to pursue self-determined goals. As Ballard remarks:

"It is precisely through their rejection of the conventions of the dominant majority, together with their skilled and creative redeployment - both individually and collectively - of the alternative resources of their imported cultural traditions that the new minorities are not only beginning to circumvent racial exclusionism, but to do so with ever increasing success ... The ethnic colonies which are now such a salient feature of innerurban life, and whose very foundation lies in vigorous networks of mutual support and solidarity, provides clearest possible evidence of their vitality ... Indeed the very power of ethnic resistance is its ideological autonomy: if there is one set of values around which one can confidently predict that vigorously resistant minorities will not predicate their activities, it is those which underpin their excluders taken-for-granted cultural presuppositions." 11

Or as Menski has stated in relation to law: "What if the critical element in the legal analysis of race is not in fact 'race', as much of Britain's sociological writing continues to argue, but rather something like 'ethnicity' or 'culture?'?"12 There are signs that the deprivationist model is now being applied in the case of Muslims as an underprivileged religious group, a mode of discourse with which many Muslim spokespersons are colluding, with eerie echoes of earlier decades.

Nevertheless, it is the inner dynamics and value systems of the ethnic minority groups which are crucial to analysing the character of legal reconstruction that they have pursued on British soil. But this would also imply that expectations of assimilation - that is the abandonment of one's inherited cultural traditions, and conformism to a dominant British legal culture, whatever that was - were also based upon false assumptions. ${ }^{13}$ We will need to discuss further below the impact that this realisation is having within legal scholarship. At the same time we should not delude ourselves that the British education system has necessarily assisted in the smooth reproduction of community values, with disastrous results in many cases. ${ }^{14}$ Students are thus constantly being (mis-)educated to underplay their multiple cultural heritages and this constitutes a formidable pedagogical hurdle. On a related theme, Werner Menski has pointedly remarked that: "I am sure that the contributions of young Asians to scholarship on their own

${ }^{10}$ Ballard, R. [1992]: 'New clothes for the emperor? The conceptual nakedness of Britain's race relations industry'. In: Vol. 18, No. 3 New Community, pp. 481-492 (also at: www.casas.org.uk).

${ }^{11}$ Ballard [1992] op cit.

${ }^{12}$ Menski [1997], op cit, p. 64.

${ }^{13}$ For a reiteration of the non-realisation of the assimilationist expectations see also Ballard [1994], op cit.

14 See, for example Sewell, T. [1996]: Black masculinities and schooling. Stoke-on-Trent: Trentham Books; Mehmet Ali, A. [2001]: Turkish speaking communities and education - no delight. London: Fatal Publications. 
communities are less prominent than they might have been if the climate had been more supportive for an open exchange of views." 15

Meanwhile, research on cultural diversity nationwide had for long been hindered by lack of access to clear data, possibly due to the over-concentration on 'race' and its related assimilationist assumptions. ${ }^{16}$ It was only in the 1991 Census that ethnic affiliation was measured, although even this attempt to do so has been rightly criticised on several grounds. ${ }^{17}$ It looked for the self-identification of some non-white groups through the use of ethno-national labels (Pakistani, etc.), but failed to capture identifiers that might make sense in terms of minority communities' multiple internal realities (region of origin, religion, or jati (caste), for example)..$^{18} \mathrm{It}$ failed to represent some, like the Greek and Turkish Cypriots, Yemenis and Arabs altogether, perhaps prompting the option to tick 'white'. ${ }^{19}$ The 'white' category was itself presented as uncontested and internally undifferentiated, representing the continued denial of the ethnicity of and within white majority groups - 'whiteness' is widely assumed to be the norm after all. ${ }^{20}$ The Census categorisation can thus also be construed as a form of official racism in that it impliedly problematises the non-white presence. On the other hand, there is increasing evidence that about the unease with the use of 'British' as an identifier among many ethnic minorities, precisely because the concept is still too heavily perceived as racially or ethnically coded, as already prefigured in the title of Prof. Tariq Modood's book: Not Easy Being British. ${ }^{21}$

${ }^{15}$ Menski, W. [2002]: 'Chameleons and dodgy lawyers: reflections on Asians in Britain and their legal reconstruction of the universe'. In: Britain, India and the diaspora: Changing social and historiographical perceptions [Vol. XXVIII, No. 2 Indo-British Review, Millenium issue], pp. 89-103 at p. 89.

16 Earlier, statistics were collected on the basis of the country of birth, not ethnicity as such, causing considerable problems of estimation. On implications for socio-legal research, see Menski, W. [1993]: 'Asians in Britain and the question of adaptation to a new legal order: Asian laws in Britain?' In: Israel, M. and N.K. Wagle (eds.): Ethnicity, identity, migration: The South Asian context. Toronto: Centre for South Asian Studies, University of Toronto, pp. 238-268 at pp. 239243.

17 Ballard, R. [1996]: 'Negotiating race and ethnicity: Exploring the implications of the 1991 Census'. In: Vol. 30, No. 3 Patterns of Prejudice, pp. 3-33.

18 Nesbitt, E. [1997]: “We are all equal”: young British Punjabis' and Gujaratis' perceptions of caste'. In: Vol. 4, No. 2 International Journal of Punjab Studies, pp. 202-218 points out the persisting salience of jati among younger South Asians. See Modood, T. [1998]: 'Anti-essentialism, multiculturalism and the 'recognition' of religious groups'. In: Vol. 6, No. 4 The Journal of Political Philosophy, pp. 378-399 on religion as a salient factor, despite widespread secularist assumptions.

${ }^{19}$ Struder, I. R. [2002]: Migrant self-employment in a European global city: The importance of gendered power relations and performances of belonging for Turkish women in London. Research Paper No. 74: Research papers in environmental and spatial analysis, Department of Geography, London School of Economics (at www.lse.ac.uk/Depts/geography/rp74.pdf) recently suggests this in the case of Turks settled in London.

${ }^{20}$ Recent reports indicate that English ethnic minorities in Scotland have begun to highlight cases of discrimination. This phenomenon seems to have been anticipated in general terms by Morgan, Glenn [1985]: 'The analysis of ethnicity: conceptual problems and policy implications'. In: Vol. XII, No.3 [Winter 1985] New Community, pp. 515-522, at p. 521 who observed that “...there ought to be a recognition that we live in a society composed of a number of ethnic groups, one of which is the English. The latter may be expected to become more vociferous in the defence of their ethnicity, insofar as ethnicity becomes a more important organising principle in British politics." For a poignant account of the 'invisibility' of Irish ethnicity see Mac an Ghaill, Máirtín [2000]: 'The Irish in Britain: the invisibility of ethnicity and anti-Irish racism'. In: Vol. 26, No. 1 Journal of Ethnic and Migration Studies, pp. 137-147.

${ }^{21}$ Modood, T. [1992]: Not easy being British: Colour, culture and citizenship. Stoke on Trent: Trentham; Jacobson, J. [1997]: 'Perceptions of Britishness'. In: Vol. 3, No. 2 Nations and Nationalism, pp. 181199; Parekh, B. [2000]: Report of the Commission on the Future of Multi-ethnic Britain. London: Profile Books. For a direct echo of such findings see Hoge, W. [2002]: 'Britain's nonwhites feel unBritish, report says'. In: New York Times, 4 April 2002. Paul, K. [1997]: Whitewashing Britain: Race 
With all its problems, the 1991 Census showed some interesting trends. ${ }^{22}$ Statistically, the non-European ethnic minority population is of more and more significance. The 1991 count showed that it had reached some 5.5 per cent of the UK population ${ }^{23}$, but we now await the results of the 2001 Census with eagerness - some estimates are already putting the figure at 10 per cent. ${ }^{24}$ What is even more significant is the fact of its concentration in particular urban areas of Britain. So in the larger conurbations of Greater London, Greater Manchester, the cities of the east and west Midlands, Sheffield, Scunthorpe and the textile towns in the Pennines, we find this presence to have more visibly affected the environment, local norms and cultures. Adding ethnographic information to the statistical picture, we also find that particular ethnic groups are concentrated in certain localities within these conurbations. Migration patterns based on kinship and local connections in areas of origin have significantly influenced subsequent residential choices here. ${ }^{25}$

Clearly, there is not a simple picture here, but how geographical concentration determines legal developments remains a fascinating though under-explored area of study. ${ }^{26} \mathrm{~A}$ recent case concerning Bangladeshis in East London strikingly illustrates that the alteration of local environments, with concomitant legal consequences, has not escaped the notice of alert judges. ${ }^{27}$ Current official and institutionalised emphasis on 'dispersal' ${ }^{28}$, not in itself a new idea, is a direct and, I believe, deliberate attack on the potential development of the same patterns for newer migrant communities. The frequent use, and contemplated expansion of, reporting

and citizenship in the postwar era. Ithaca and London: Cornell University Press, p. xiv remarks that nationality law revisions in the post-war period have reinforced the racial connotations behind 'Britishness'.

22 See, in detail, Peach, C. (ed.) [1996]: Ethnicity in the 1991 Census. Volume two: The ethnic minority populations of Great Britain. London: HMSO.

${ }^{23}$ The 5.5 per cent figure, broken down further, shows 2.7 per cent as South Asian, 1.6 as 'Black' (including African, Caribbean and 'other' categories) and 0.7 per cent as being Chinese and 'other-Asian' people. See Mason, D. [1995]: Race and ethnicity in modern Britain. Oxford: Oxford University Press, pp. 32-35; and Peach [1996] op cit in detail.

24 Travis, A. [2001]: 'Ethnic minorities grow to 1 in 10'. In: The Guardian, 23 February 2001, reporting a statement to that effect by Jack Straw, then Home Secretary.

25 Robinson, V. [1986]: Transients, settlers and refugees: Asians in Britain. Oxford: Clarendon Press. For this phenomenon in different stages of London's history, see Kershen, A. J. [1997]: London: The promised land? The migrant experience in a capital city. Aldershot: Ashgate, p. 5. Even with upward mobility and 'gentrification', onward migration away from older industrial centres is not necessarily individualistic, but may be determined by ethnic and kinship affiliations. See Werbner, P. [1979]: 'Avoiding the ghetto: Pakistani migrants and settlement shifts in Manchester'. In: Vol. 7, No. 3 New Community, pp. 376-389.

${ }^{26}$ But see already: Menski, W. F. [1988]: 'Uniformity of Laws in India and England'. In: Vol. VII, No. 11 Journal of Law and Society (University of Peshawar, Pakistan), pp. 11-26 at pp. 11-12. This hard-to-find article has now been usefully reproduced in Menski, W.F. [2001]: Modern Indian family law. Richmond, Surrey: Curzon, pp. 360-373. See also Pearl, D. and W.F. Menski [1998]: Muslim family law. London: Sweet and Maxwell. 3rd ed., pp. 59-61. Ethnic minority-state relations most obviously manifest at local levels as discussed by Nielsen, J. [1988]: 'Muslims in Britain and local authority responses'. In Gerholm, T. and Y Lithman (eds.): The new Islamic presence in Western Europe. London: Mansell; Nielsen, J. [1992]: Islam, Muslims, and British local and central government. Paper presented at conference on Muslims in Europe, Turin, 4-5 May 1992. Saggar, S. [1996]: 'The politics of racial pluralism in Britain and problems of evaluation'. In: Barot, R. (ed.): The racism problematic. Comtemporary sociological debates on race and ethnicity. Lewiston et al: The Edwin Mellen Press, pp. 166-192 argues, more ominously, that policy decisions were taken at the highest levels earlier in the post-War period to ensure that debates on pluralisation of British society would remain concentrated at local levels thereby avoiding wider, national debates on policy taking place.

${ }^{27}$ See the fascinating case Re S (Change of Names: Cultural Factors) [2001] FLR 1005, Wilson J.

${ }^{28}$ Harvey, C. [2000]: Seeking asylum in the UK: Problems and prospects. London et al: Butterworths, pp. 195-196; Shah [2000], op cit, pp. 199-200. 
requirements for asylum seekers, as well as planned residence restrictions, can then be seen as bolt-on mechanisms for dispersal, to keep people in their place, so to speak.

\section{Problematising prevailing paradigms}

In analysing the response of scholarship, and hence approaches to teaching, about ethnic minorities in law, we need to recognise the profound ambivalence that the British (and Western) legal tradition has about the reconstruction of Afro-Asians legal orders in the diaspora. Of necessity, therefore, we have to begin with a deconstructive exercise, by questioning the assumptions and limitations of the prevailing jurisprudence, before engaging with alternative, agency-oriented perspectives and the more substantive issues.

In Britain the tradition of legal responses to the presence of Afro-Asian minorities has been through the prism of the Race Relations Acts. This was in keeping with the privileging of 'race' that otherwise expected conformism to the equal citizenship model premised on assimilation in cultural terms. As Lester and Bindman pointed out some thirty years ago, this involved a fundamental contradiction, since immigration laws were most often targeting the very same people whom the anti-discrimination laws seemingly sought to protect. ${ }^{29}$ Nevertheless, the current Race Relations Act 1976 is predicated on the processing of individual grievances. I would suggest that this sort of response has been seen as appropriate precisely because more generalised exclusionary patterns can thereby be individualised, and largely made containable, than if they were treated as group phenomena. ${ }^{30}$ This is why the recent extension of the Race Relations Act to the exercise of public powers, including immigration control, can easily co-exist with racist immigration policies. Indeed, we see that when group issues arise through this legislation the legal system begins to appear unable to handle their implications.

It is possible that when framing the definition of 'racial groups' the drafters of the 1976 Act had not realised the difficulties that the courts would face, and that they would themselves in turn create. The definition of 'racial groups' includes 'ethnic groups' and we have seen how ethnic group status has come in recent years to be much more significant in official terms. It seems that patterns of differential treatment within the operation of the anti-discrimination law have now been created as people who claim protected status as members of ethnic groups have approached judges. ${ }^{31}$ Sikhs may therefore legitimately complain about discrimination against those who wear turbans to cover uncut hair, but Rastas cannot claim that they too regard maintenance of long hair as a sacred duty. While the law accords racial group status to whites, including Jews and Welsh as well as Japanese, without much fuss, Muslims and Hindus find it an uphill struggle to be recognised. This implicates the legal system in a complex politics of recognition whereby admission to membership of a protected category is made to look more like a favour. ${ }^{32}$

It is obvious today that the Afro-Asian presence in the UK clearly has implications beyond the anti-discrimination and immigration law fields. ${ }^{33}$ By the time that Werner Menski had

\footnotetext{
${ }^{29}$ Lester, A. and Bindman, G. [1972]: Race and law. Harmondsworth: Penguin, pp. 13-15.

30 Discrimination remains a common phenomenon excluding non-European ethnic minorities from employment opportunities. Mason [1995], op cit, pp. 58-61.

${ }^{31}$ Jones, R. and Welhengama, G. [2000]: Ethnic minorities in English law. Stoke on Trent: Trentham, pp. 27-57.

32 Menski [1997], op cit, pp. 67-68. One should note that the Council Directive 2000/78/EC will allow individuals to claim protected status on the basis of their 'religion or belief' by 2 December 2003, albeit only as concerns discrimination within the employment field. Why religion has merited treatment separately from 'race' and 'ethnicity', as provided for by Council Directive 2000/43/EC, would be an interesting area of research. One may speculate that traditions of secularism and Christian pre-dominance throughout the EU may have been behind reservations about minority religious claiming protection in fields other than employment. The fuss over Muslim women wearing headscarves in several EU Member States is a case in point.

33 On the earlier predominance of these fields see Poulter, S. [1986]: English law and ethnic minority customs. London et al: Butterworths. [1986]: p. vi; Menski [1997], op cit, pp. 65-66.
} 
started teaching the course on Ethnic Minorities and Law at SOAS this earlier focus was beginning to give way to more diverse coverage with the surfacing of some key writing. Sebastian Poulter's English law and ethnic minority customs and David Pearl's Family law and the immigrant communities, both published in 1986, discussed a whole range of legal issues raised by the settlement and increasing presence of non-European ethnic minorities of immigrant origin. The focus remained very much on the conflicts of law (or private international law) perspective, however, which typecast ethnic minority issues as involving 'foreign' legal rules within an English (or UK) context. It was not conceded that recently settled ethnic minorities would have to, sooner or later, be seen as further pluralizing (even Orientalising!) the English legal system. We were, at that stage, probably still at the point where it was thought that the loosening of links abroad, and therefore reliance on overseas domicile, would inevitably result in large-scale recourse to English legal norms. This was particularly so for the English-born or -raised generations with their exposure to the British education system. Indeed, it remains vitally important to discuss how the conflicts of law approach has changed since the signs of acceptance of plurality in the early 1970s. There is evidence that the official approach was considerably tightened to curb signs of judicial independence in this area that would have allowed widespread recourse to non-English laws. ${ }^{34}$ An over-concentration on the conflicts approach nevertheless carries the implication that ethnic minority legal issues continue to be seen as 'foreign' therefore what further was there to discuss about those who have adopted Europe as their home - surely the lex loci will and should prevail! But there is an increasing consciousness that this approach is no longer adequate. ${ }^{35}$

In official terms, however, recognition of ethnic diversity has led to hardly any acknowledgement of its manifold legal implications, with minimal impact at teaching and academic level also.36 To be sure, Poulter's prolific contributions offered one way of conceptualising the Afro-Asian presence beyond the traditional conflicts approach. He did argue that the state had to tolerate ethnic diversity at the very least in the interests of social peace, albeit within limits. However, one indicator of Poulter's ambivalent approach was his choice of terminology which carried significant policy implications. He spoke of "ethnic minority customs" 37 and later also of "Asian traditions" 38 rather than "laws". As he stated:

"Legal recognition must be afforded to many ethnic minority customs on grounds of practicality, commonsense, individual liberty, religious tolerance and the promotion of racial harmony. However, a few restrictions and limitations must equally be imposed, in the interests of public policy, to protect certain core values in English society and to obviate any genuine and reasonable claim by the majority that ethnic minorities are obtaining preferential treatment or special dispensations which cannot be justified by reference to established legal principles. In drawing a suitable dividing line, reference may usefully be made to the provisions of those international treaties to which the UK is

\footnotetext{
${ }^{34}$ For a favourable early approach by the courts see Qureshi v. Qureshi [1971] 1 All E.R. 325; [1972] Fam 173; [1971] 2 WLR 518. For evidence of restrictionism from this period in the area of recognition of ethnic minority divorces see Pearl and Menski [1998], op cit, pp. 382-398; Jones and Welhengama [2000], op cit, pp. 118-132 and Mayss, A. (2000): 'Recognition of foreign divorces: unwarrantable ethnocentrism'. In: Murphy, J. (ed.): Ethnic minorities, their families and the law. Oxford, UK and Portland, Oregon: Hart, pp. 51-70.

${ }^{35}$ For two European discussions on this question see Foblets, M.-C. [1999]: 'Conflicts of law in cross-cultural family disputes in Europe today. Who will reorient conflicts law?' In: Foblets, M.C. and F. Strijbosch (eds.): Relations familiales interculturelles/Cross cultural family relations. Oñati: International Institute for the Sociology of Law, pp. 27-45 and Ferrari, S. [2000]: 'Introduction'. In: Ferrari and Bradney [2000] op cit, pp. 1-9 esp. at pp. 6-8.

36 Menski [1997], op cit. It is no coincidence that Ferrari [2000] op cit, p. 6 poignantly argues for the reintroduction of the teaching of the laws of religions as a way of bridging the knowledge gap about the legal issues of importance to the Muslims of Europe.

${ }^{37}$ Poulter [1986], op cit, pp. 3-4.

38 Poulter, S. [1990]: Asian traditions and English law. Stoke on Trent: Trentham and Runnymede Trust.
} 
a contracting party which are designed to protect human rights and fundamental freedoms." 39

More recently, Poulter wrote:

"While English law should broadly approach other cultures in a charitable spirit of tolerance and, when in doubt, lean in favour of allowing members of minority communities to observe their diverse traditions here, there will inevitably be certain key areas where minimum standards, derived from shared core values, must of necessity be maintained if the cohesiveness and unity of English society is to be preserved intact." 40

Suggesting that minority traditions should be viewed as customs, rather than anything specifically legal, therefore allows Poulter to posit that English law may retain the freedom to choose between those elements that it wishes to see continue and those which it does not. In this respect, the difficulty of establishing the existence of customs generally under English law is instructive. ${ }^{41}$ The treatment of ethnic minority customs as disposable may also overstate the prospects of enforcing uniformity given our observations above about the unrealism of expecting assimilation. Poulter here also tries to drive home the message that conformity to English norms, and therefore assimilation, is demanded as a condition of acceptance. In that case it is difficult to resist the conclusion that English law remains very much culture-bound and really quite ethnocentric. The invocation of human rights treaties as a means of finding a minimum set of agreed-upon values is an unfortunate resort to a legitimating device that disregards the contested environment in which such apparently universalising treaties exist. This reinforces the ethnocentric nature of Poulter's analysis $^{42}$ though it can be expected that an emphasis on human rights will discourage all but the most critical and confident students from raising concerns about this problem.

Another writer, Lucy Carroll, who has taken on the challenge of analysing the status of Muslim laws in the context of the growth of a parallel Muslim court system in Britain, writes:

"It is important to realize that in the modern world Islamic law, as law, does not exist as some disembodied entity floating in the stratosphere, overreaching national boundaries and superseding national law. In the modern world, Islamic law exists only within the context of a nation-state; and within the boundaries of any particular state it is only enforced and enforceable to the extent that, and subject to the reforms and modifications that, the nation-state decrees."

Carroll here tries to reinforce the message that whatever the feelings of Muslims, they cannot expect to follow Islamic law in Britain. This underlines the persistence of 'legal centralism' in that the state and its court system are given all power to territorially delimit the application of ethnic minority and, indeed, any other, non-state legal orders. ${ }^{43}$ These writers therefore reflect types of dominant, state-focused perspectives that continue to de-status ethnic minority laws in Britain. ${ }^{44}$ A by-product of such approaches is precisely to advantage those members of ethnic minority

39 Poulter [1986], op cit, pp. v-vi.

40 Poulter, S. [1998]: Ethnicity, law and human rights. Oxford: Clarendon, p. 391.

${ }^{41}$ See, for example. Zander, M. [1989]: The law-making process. 3 ${ }^{\text {rd }}$ ed. London: Weidenfeld and Nicolson, pp. 375-384. For an account of the idea of custom in Western thought more generally, as well its eclipse in the modern era, see Kelley, D. R. [1997]: "Second nature": the idea of custom in European law, society and culture'. In: Kelley, D. R.: The writing of history and the study of law. Aldershot: Variorum/Ashgate, pp. 131-172.

42 Menski [1997], op cit, p. 70; Shah, P. [2000]: 'Ethnic minorities and the European Convention on Human Rights'. In: Ian E. (ed.) (2000): Comparative law in global perspective. Ardsley, New York: Transnational Publishers, pp. 387-410.

43 The phrase 'legal centralism' and its connotations are discussed by Griffiths, J. [1986]: 'What is legal pluralism?’ In: No. 24 Journal of Legal Pluralism and Unofficial Law, pp. 1-56.

${ }^{44}$ See critically Menski [1993], op cit, Menski [1997], op cit, p. 70, Jones and Welhengama [2000], op cit, pp. 97-106. 
communities who can or are willing to navigate between legal systems and who will try to fool lawyers and judges by effectively abusing 'tradition'. On the other hand, those who do not have these means are penalised and often exploited by those in the former group, and there is growing evidence that this is hitting women and children in particular. ${ }^{45}$ Politically correct claims to be seeking gender justice thus seem to ring hollow in the case of ethnic minority women who find themselves doubly disenfranchised under English law.

\section{Teaching and doing legal pluralism}

If the British legal order largely expects conformity, refuses to fully recognise diversity, and penalises people for cultural hybridity, is there a framework of legal inquiry that can help us to approach things more positively? Our response has inevitably had to involve a departure from the way in which law was being taught elsewhere and as it was (and is) generally presented in the leading textbooks regardless of which topic is dealt with in particular. Indeed, it has been essential to start from 'basics' and pose questions questions about how we conceptualise 'law'. We therefore question the fundamental premises of Western 'model jurisprudence'46, as a way of eventually understanding that the legal situation of Afro-Asian (and indeed any other) ethnic minorities (or majorities) cannot be adequately analysed within traditionally accepted 'black-letter' renderings. ${ }^{47}$ Further, we try also to de-centre 'legal centralist' presuppositions by showing that the claims of modernist legal thought are far from realisable in practice. Official state-based legal systems simply cannot control everything, and theoretical and ontological space is also needed for 'civil society'.

For critiques most relevant to a study of ethnic minorities in Western legal systems we turn to legal-pluralist writers, most of whom have actually been concerned with the nature of non-Euro-American legal systems. ${ }^{48}$ At a general level, legal pluralist theories argue that 'law' can be generated by different sources, whether recognised by the state or not. This idea is often shocking to people schooled only in Western law possibly because it concedes too much to the people who would then also have to be viewed as law-making agents in their own right. ${ }^{49}$ Some pluralist writers also imply that the state and lawyers end up obtaining too much power by overemphasising top-down structures that undermine the power of self-regulation within the society or societies concerned. Others have sought to highlight that an approach to legal study that ignores social, cultural or religious fields neglects an important component of the 'law' itself, how it operates and its effectiveness and relevance. Pluralist theories therefore also open up avenues for arguing that 'law' is very much determined by one's cultural presuppositions. Immediately, strongly-held beliefs about pursuance of legal uniformity as a mark of a developed

${ }^{45}$ Menski [1993], op cit, Pearl and Menski [1998], op cit, Shah-Kazemi, S. N. [2001]: Untying the knot. Muslim women, divorce and the shariah. London: Nuffield Foundation. See Menski [2002], op cit, now on abuse of tradition in the courts.

${ }^{46}$ Chiba, M. (ed.) [1986]: Asian indigenous law in interaction with received law. KPI: London and New York.

${ }^{47}$ For the persistence, and trenchant criticism, of a 'black-letter' approach to legal education as well as its implications for teaching legal ethics, see Hutchinson, A. C. [1999]: 'Beyond back letterism: ethics in law and legal education'. In: Vol. 33, No. 3 Law Teacher, pp. 301-309.

${ }^{48}$ Hooker, M. [1975]: Legal pluralism: An introduction to colonial and neo-colonial laws. Oxford: Oxford University Press; Moore, S. F. [1978]: Law as process. An anthropological approach. London et al: Routeledge \& Kegan Paul; Chiba [1986], op cit, and Griffiths [1986], op cit. This material is now very usefully been summarised, explained, and contrasted with dominant Western approaches, by Menski, W.F. [2000]: Comparative law in a global context. The legal systems of Asia and Africa. London: Platinium, pp. 51-137. In brief, see Jones and Welhengama [2000], pp. 91-96.

${ }^{49}$ In this context the observations made about the blinkers that legal education seems to put onto students' vision made by Conaghan, J. [2002]: 'Law, harm and redress: a feminist perspective'. In: Vol. 22, No. 3 Legal Studies, pp. 319-?? at pp. 319-321 are especially apposite. In that sense one of the challenges for ethnic minority legal studies, as for feminist legal studies, is precisely to try to enable critical thinking about law to take place. 
and modern legal system are also put into doubt, especially when one is working within a polyethnic context. For students at SOAS, this material has been largely palatable and digestible since they are used to such notions as the operation of 'personal laws' in Asia and Africa. It encounters resistance elsewhere, however. There is an interplay of several factors here. Schooling in nonEuro-American legal systems is just not available widely enough; theorising in that field also suffers from the homogenising claims of development or globalisation oriented scholarship; and it is wrongly assumed that personal law systems were simply a colonial by-product or a British invention and therefore to be viewed as a mark of submission in the post-colonial era. The prevalence of caricatures and stereotypes of Afro-Asian legal systems can then easily be used to discredit attempts at deeper analysis.

However, an emerging literature taking an agency-oriented approach to the situation of migrants and their offspring has now begun to discuss the implications of the diversity of legal cultures in Britain. ${ }^{50}$ From legal pluralist perspectives, ethnic minorities of immigrant origin are themselves seen as navigating among different legal orders, thereby reconstructing Afro-Asian laws in hybrid forms. This means that their traditional obligation systems are still understood by members of these communities as paramount, while they are seen to build in the requirements of official law as necessary or expedient. A specifically Muslim variant of this is termed angrezi shariat, an Urdu term simply meaning British-Muslim law. That discerning these elements of legal behaviour means having specifically to take account of unofficial practices means that our bookbased laws are of much less relevance; an examination of the law reports or a textbook on any key area of English law will still not yield much information about the operation of British-Hindu or British-Yoruba laws precisely because they are relegated to unofficial status and therefore considered irrelevant to dispute resolution in the courts.

The publication by the Lord Chancellor's Department of the Equal Treatment Bencbbook and its vigorous promotion by Lord Justice Brooke, as well as ethnic minority awareness training for magistrates and judges, is certainly to be welcomed in this regard, although students have immediately questioned whether this approach is really not tokenism or simply too little. All this does, however, mean that people with field knowledge become especially important in providing information about reconstruction of Afro-Asian laws. Given that there are very few persons with such training, and that few law departments have seriously acknowledged its relevance, means that we have to rely on anthropologically inclined colleagues, who are specifically interested in bottom-up field observations, to supply the necessary skills and knowledge.

Such persons are also increasingly sought by lawyers in practice to provide expert background information in order to shed further light on cases they are handling. Both Menski and Ballard have argued that the common law system, with its case-by-case approach, is potentially suited to meeting the demands of justice in such disputes, provided that courts are brought up to speed on ethnic minority issues involved. However, Menski has observed that the lack of adequate information and appropriate training for lawyers, who act as key gatekeepers, means that by the time a dispute will reach the courts the 'ethnic' elements in it will have been twisted out of recognition if not altogether eliminated. ${ }^{51}$ Ballard, on the other hand, has expressed some disappointment with the higher judiciary after crucial information in criminal cases has been dismissed as irrelevant. ${ }^{52}$

I have found that such material produced by experts, now growing in various private collections, is a very useful supplement to our existing teaching tools. While students often find

\footnotetext{
${ }^{50}$ Menski [1993] op cit, Pearl and Menski [1998], op cit, pp. 51-83; Menski, W. [2001]: 'Muslim Law in Britain'. In: No. 62 Journal of Asian and African Studies (Tokyo University of Foreign Studies), pp. 127-163; Menski [2002], op cit:; Yilmaz, I. [2000]: 'Muslim law in Britain: Reflections in the socio-legal sphere and differential legal treatment'. In: Vol. 20, No. 2 Journal of Muslim Minority Affairs, pp. 353-360; Yilmaz, I [2001]: 'Law as chameleon: The question of incorporation of Muslim personal law into the English law'. In: Vol. 21, No. 2 Journal of Muslim Minority Affairs, pp. 297-308; Yilmaz, I. [2002]: 'The challenge of post-modern legality and Muslim legal pluralism in England'. Vol. 28, No. 2 Journal of Ethnic and Migration Studies, pp. 343-354.

${ }^{51}$ Menski [1993], op cit, pp. 251, 253. For a more recent critique, see Menski [2002], op cit.

52 Ballard, R. (n.d.): 'Common law and uncommon sense: the assessment of reasonable behaviour in a plural society', at: www.casas.org.uk.
} 
intuitive appeal in reading legal pluralist perspectives they are often much more reserved about their practical value. The use of expert reports therefore enables students to see how field knowledge can actually be applied in real casework contexts, thereby opening the door to discussions about how legal pluralism could work in practice or, as one colleague recently remarked, how one can do legal pluralism. I am convinced, despite what may be apparent from our law reports, that a huge market exists out there for such work as long as we are able to train people with the right sort of skills. While this should also open up a more lively debate about the role of experts within the legal system, it is beginning to appear that, for the moment, and despite official reluctance to admit that we are moving towards a sort of Afro-Asian personal law system in Britain, this role is vital in ensuring ethno-sensitive service provision. ${ }^{53}$

\section{Curricular concerns}

We have seen then that there are considerable conceptual hurdles that need to be confronted and discussed as a necessary precondition to engagement with the more substantive aspects of teaching about ethnic minorities in law. Here, one will most likely be developing on one's own areas of strength and research interest. The traditional areas of concentration in this field, of immigration and anti-discrimination law, continue to be of relevance. From a relatively marginal position, they have indeed risen to prominence in practice in recent years. ${ }^{54}$ But the potential range of other topics that can be covered is huge. Besides immigration and anti-discrimination law and the conceptual issues that have been discussed above we have tended to focus on the following legal areas: family law, criminal law, racial harassment and violence, mental health, blasphemy and education. There is certainly room for further diversification and various other issues such as business, planning, housing, legal education and the legal professions could be included.

One key issue will be that of teaching materials. Using law reports as a teaching tool is, of course, indispensable. However, law reporting remains fraught with its own politics that have ensured the systematic non-appearance of cases of crucial relevance to ethnic minority laws. We can be sure that reports represent merely the tip of the iceberg when it comes to ethnic minority legal disputes many of which will never be presented before official fora as traditional avoidance mechanisms come into play. ${ }^{55}$ We have also noted above how the 'ethnic' elements in disputes may be engineered out of the hearing by lawyers or claims about 'tradition' may even be raised to the unfair advantage of one party. With cases that do appear in the reports there will be issues as to precisely how to interpret the background as well as the result as presented by judges. Discussing the various 'visible' and 'invisible' elements in judgements provides a fascinating area of critical legal education in itself. ${ }^{56}$

Articles, largely though not exclusively, derived from the minority press have been a key source of information showing how the social basis of the legal system is changing ethnically, and in ways which are barely discussed in the academic literature. Although matters are improving, reliance on 'unorthodox' sources is still necessary; academic writing has simply not caught up in this respect. Besides, there are some types of issue that would seldom be brought to light in textbook form. The Stephen Lawrence case that led to some incisive questioning of the criminal justice system by MacPherson's team, or the trial of the Leeds footballers charged for crimes of a

${ }^{53}$ Menski [2002], p. 101 remarks that: "We are in a sense back to the methods of the late $18^{\text {th }}$ and $19^{\text {th }}$ century, when courts in British India employed pandits and moulvis to guide them on details of the respective personal law."

54 Complementing the Immigration Law Practitioners' Association there is also now the Discrimination Law Association. Both organisations offer multiple advantages and, for academics, a way of keeping in regular touch with practice issues.

${ }^{55}$ See Menski [1993], op cit, at p. 255.

56 A good 'test' case here is Kaur v Singh [1972] 1 All ER 292 where the judge accepts the claim that it is normally the duty of the groom's side to make the arrangements for a Sikh wedding. I am constantly amazed by how many students, even those of South Asian background, fail to spot how the judge was misled about this. 
racist nature against an Asian youth, I have found, can be fruitfully discussed through the press reporting that they received. Another valuable source of information has been non-legal academic writing, particularly by social science colleagues. Again, it is here that many issues are being addressed that are not being built into legal writing, because they are dismissed from legalcentralist perspectives as 'extra-legal'. Teaching in this area therefore necessarily requires some inter-disciplinary navigation..$^{57}$ This may result in complaints from law librarians, but there may be ways in which inter-departmental resources can be pooled, thus making the most of existing material.

A more general curricular concern is whether one should teach a course on Ethnic Minorities and the Law as a separate optional offering, or whether an ethnic minority focus ought to be integrated into all areas of teaching. In principle, I am certainly in favour of the latter approach. Indeed, if it is accepted that police, magistrates, judges and other officials are prone to institutional racism, and that training is essential to mitigate its effects, then it would now seem impossible to argue that students should not be taught about how what implications ethnic diversity in Britain has for all areas of law. Indeed, on this basis one ought to be able to argue for resources dedicated to building diversity programmes in al law departments. However, I do not yet see a movement in this direction - mainstream legal writing, and therefore also education, continues to remain overwhelmingly 'culture blind'. Building in plurality-conscious approaches into every area of law would have implications for the underpinnings of every course as one would be forced to recognise the relativity in cultural terms even of the 'majority' areas, and their claims to ideological dominance would thereby be severely compromised. I recently argued, and was criticised for doing so, that post-war writing on public law has taken virtually no account of Britain's changed ethnic character and it is certain that the same can be said of all mainstream areas of law teaching in Britain. ${ }^{58} \mathrm{~A}$ real danger still exists that separate optional courses on ethnic minorities can be pushed further into an 'ethnic niche', so that other academics can comfortably avoid taking seriously the need for changes in their own curricula. This should not, in any case, deter committed individual teachers from being more adventurous in their own repertoires.

${ }^{57}$ Menski [1997], op cit, pp. 64-66, 71.

${ }^{58}$ Shah, P., 'Implications of immigration for the British constitutional order: overt and hidden', paper presented at the conference on Global Migrations/Domestic Reactions: A Comparative Constitutional Perspective, 24 May 2002, Oxford Brookes University, Oxford. This does not mean that there are no changes at all in response to ethnic diversity. A new edition of Hoggett and Pearl [2002]???], a leading family law undergraduate coursebook has, in its first chapter, a sizeable extract from the Equal Treatment Benchbook discussing the diversity of family structures in Britain today. Unfortunately this has allowed the rest of the book to maintain a 'culture blind' perspective, with the strong suggestion that official English law remains the dominant ordering system among ethnic minorities too. 